\title{
THE TIME OF PATRIARCHS PETER IV AND DAMIAN AS THE NODAL POINT OF THE GENESIS OF THE COPTIC CHURCH: PROBLEMS AND PROPOSED SOLUTIONS
}

\author{
Anton A. Voytenko \\ Centre for Egyptological Studies of the Russian Academy of Sciences, Moscow, Russian Federation
}

\begin{abstract}
Introduction. The article examines a recently put forward hypothesis that the time of the Coptic Church's final genesis was the period of the Alexandrian anti-Chalcedonian Patriarchs Peter IV (576-578) and Damian (578-607). Methods. A comparative research method and factor analysis are used. The main research task is to identify all the factors that contributed to the making of full-fledged ecclesiastical structures by the Theodosians (one of the trends of the Egyptian Miaphysites), and a correlation of these factors with each other to single out the main of them. Analysis. The successful establishment of the Miaphysites (Theodosian) episcopate resulted from the configuration of objective and subjective factors. Objective factors include the following: the weakening of control by the central authorities over the structures of the Miaphysites after Justinian I (482/483-565), the increasing regionalization of the empire and the strengthening of the role of local elites in the provinces, the growing importance of the Coptic language in secular and clerical office work. Subjective factors include the victory of the Miaphysite Patriarch Peter IV over his rival Theodore and the appearance of Damian as Peter's successor. Results. On the whole, the proposed hypothesis quite thoroughly explains the emergence of the Coptic Church during the period. However, it has several disadvantages, which open up a number of prospects for further researches. Firstly, there is almost no explanation for the success of Damian's personnel policy. Secondly, insufficient attention was paid to the Egyptian anti-Chalcedonian monasticism. From the author's point of view, Egyptian Miaphysite monks, suffering from the pressure of the central and local authorities after the Chalcedonian schism, managed to establish an effective network functioned as a "rhizome", on which the episcopate risen during Peter's and Damian's time relied primarily in rebuilding stable ecclesiastical structures in Egypt.

Key words: history of the Byzantine Church, Byzantine Egypt, Coptic Church, Egyptian monasticism, Miaphysitism.

Citation. Voytenko A.A. The Time of Patriarchs Peter IV and Damian As the Nodal Point of the Genesis of the Coptic Church: Problems and Proposed Solutions. Vestnik Volgogradskogo gosudarstvennogo universiteta. Seriya 4. Istoriya. Regionovedenie. Mezhdunarodnye otnosheniya [Science Journal of Volgograd State University. History. Area Studies. International Relations], 2021, vol. 26, no. 6, pp. 304-317. (in Russian). DOI: https://doi.org/10.15688/jvolsu4.2021.6.22
\end{abstract}

УДК $94+281.4+281.71$

Дата поступления статьи: 14.02.2021

ББК $63.3(0) 4$ Дата принятия статьи: 10.10.2021

\section{ПАТРИАРШЕСТВО ПЕТРА IV И ДАМИАНА КАК ВРЕМЯ ГЕНЕЗИСА КОПТСКОЙ ЦЕРКВИ: ПРОБЛЕМЫ И ПРЕДЛАГАЕМЫЕ РЕШЕНИЯ}

\section{Антон Анатольевич Войтенко}

Центр египтологических исследований РАН, г. Москва, Российская Федерация 
ноценных церковных структур у феодосиан (одного из течений египетских миафизитов), корреляция этих факторов между собой и выделение среди них основных. Анализ. Успешному созданию миафизитского (феодосианского) епископата способствовала конфигурация объективных и субъективных факторов. К объективным можно отнести следующие: ослабление контроля со стороны центральной власти за структурами миафизитов после Юстиниана I (482/483-565 гг.), возрастание регионализации империи и усиление роли местных элит в провинциях, усиление роли коптского языка в церковном и светском делопроизводстве. К субъективным факторам можно отнести победу миафизитского патриарха Петра IV над своим конкурентом Феодором и появление Дамиана в качестве преемника Петра. Результаты. В целом, предложенная гипотеза достаточно основательно объясняет возникновение Коптской Церкви именно в этот период. Однако она имеет несколько недостатков, открывающих ряд перспектив для дальнейших исследований. Во-первых, почти никак не объясняется успех кадровой политики, которую проводил Дамиан. Во-вторых, недостаточно внимания было уделено египетскому миафизитскому монашеству. Последнее, с точки зрения автора статьи, при очевидных сложностях и давлении центральных властей, сумело после халкидонского раскола создать эффективную сеть, функционировавшую как «ризома», на которую в первую очередь опирался возникший во время Петра и Дамиана епископат при отстраивании устойчивых церковных структур на территории Египта.

Ключевые слова: история византийской Церкви, византийский Египет, Коптская Церковь, египетское монашество, миафизиты.

Цитирование. Войтенко А. А. Патриаршество Петра IV и Дамиана как время генезиса Коптской Церкви: проблемы и предлагаемые решения // Вестник Волгоградского государственного университета. Серия 4, История. Регионоведение. Международные отношения. - 2021. - Т. 26, № 6. - С. 304-317. DOI: https://doi.org/10.15688/jvolsu4.2021.6.22

Введение. Время окончательной институционализации, вероятно, одной из наиболее многочисленных и влиятельных миафизитских Церквей - Коптской Церкви - остается предметом дискуссий. Ранее предлагалось два возможных решения этого вопроса. Первый, на котором настаивает сама Коптская Церковь, гласит, что она ведет свою историю от проповеди в Александрии апостола Марка и основании им здесь общины христиан. Но на подобную преемственность претендует и Александрийский православный патриархат. Согласиться с этим мнением фактически означает передать пальму первенства одной из ныне существующих Церквей вместо того, чтобы объективно признать «традицию Марка» общей для двух христианских конфессий Египта, впоследствии разошедшихся и христологически и этнически (немногочисленный Александрийский патриархат сейчас состоит, в основном, из этнических греков и православных арабов).

Второе решение предлагает начинать отсчет генезиса двух Церквей с даты Халкидонского собора (451 г.), что, на первый взгляд, представляется довольно логичным. Однако, если такое предположение верно для Александрийского патриархата, после Собора, безусловно, представлявшего собой полноценную церковную структуру, то для египетских не- халкидонитов ${ }^{2}$ это решение вряд ли можно назвать удачным. Сразу после Собора при очевидном давлении на них византийских властей им не удалось создать полноценной церковной структуры: слабым звеном здесь являлся епископат, долгое время существовавший в «мерцающем» режиме. Мало того, объективные данные, известные нам по источникам, показывают, что за период патриаршества Феодосия, вынужденного пребывать в ссылке при константинопольском дворе, нехалкидонских епископов было явно недостаточно, чтобы институционализировать египетских миафизитов до той степени, которая отличает церковную организацию от «сетевой» альтернативной деноминации. Более чем столетний период после Халкидона можно, таким образом, назвать предысторией миафизитской Церкви Египта, или даже периодом бифуркации, когда окончательного сценария развития ее структуры еще не существовало.

Наконец, совсем недавно был выдвинут ряд аргументов в пользу того, что временем окончательного генезиса нехалкидонской Церкви Египта являлось время патриархов Петра IV (576-578 гг.) и Дамиана (578-607 гг.) ${ }^{3}$. Именно в это время египетским миафизитам удалось создать полноценную церковную структуру, причем устойчивую до такой степени, что она благополучно прошла период серьез- 


\section{ВИЗАНТИЙСКОЕ ПРАВОСЛАВИЕ}

ной турбуленции, связанной с арабским завоеванием Египта. Дополнительным основанием в пользу этого решения является предположение, что те особенности исторической памяти, которые во многом характерны для современной религиозной идентичности коптов, складываются именно в этот период. Анализу этих аргументов, их сильным и слабым сторонам, а также рассмотрению альтернативных сценариев развития Коптской Церкви в ранневизантийский период и посвящена данная статья.

Материалы и методы. Основными материалами, анализируемыми в статье, являются работы современных западных ученых, прежде всего, две статьи Ф. Бута [8; 9], в которых было предпринято серьезное исследование большой источниковой базы и выдвинут ряд интересных положений об исключительной важности периода патриархов Петpa IV и Дамиана как времени окончательного становления миафизитской церковной структуры в византийском Египте. Очень важным для данной темы является и недавнее исследование Р. Деккер [12; 4], посвященное созданию и особенностям функционирования феодосианской церковной сети в регионе Фив, где в качестве одного из основных инструментов исследования был применен метод анализа социальных сетей (Social Network Analysis=SNA) ${ }^{4}$. Значительным подспорьем в нашей работе оказались выводы наших собственных исследований $[1 ; 3 ; 19]$, а также исследования Э. Випшицкой $[20 ; 21]$. Там, где это было необходимо, привлекались данные источников, главным образом, гомилетики (например, проповедь Писентия, епископа Коптоса, в день памяти св. Онуфрия, панегирик Стефана, епископа Гераклеопольского, Аполлонию, традиция об Аврааме из Фаршута), а также данные из «Церковной истории» Иоанна Эфесского и др.

Основным методом исследования послужил метод сопоставительного анализа, а также факторный анализ. Факторный анализ сравнительно редко применяется в гуманитарных исследованиях (за исключением, может быть, психологии). Основной его задачей является всестороннее, но в то же время компактное описание объекта исследования, а также выявление скрытых факторов, отвеча- ющих за наличие корреляций между переменными величинами. В нашем случае основной исследовательской задачей было обнаружение (на разных уровнях) всех факторов, которые могли способствовать созданию устойчивой и конкурентоспособной церковной структуры египетских миафизитов и определение тех, которые могли бы считаться основными. Для реконструкции альтернативного сценария развития церковных структур противников Халкидона применялся метод научного моделирования, заключающийся (в данном случае) в генерировании на базе содержащейся в источниках информации возможного пути их развития при удалении из общей картины одного из основных условий - возможности создания в конце VI в. полноценного миафизитского епископата. Подобный опыт был предпринят в том числе и для того, чтобы более «объемно» представить ту значимость, которую, на наш взгляд, представляло собой миафизитское монашество как фактор, придающий необходимую устойчивость церковным институтам нехалкидонитов (как в идейном, так и в организационном смысле).

Анализ. Точкой отсчета нового периода в истории египетских нехалкидонитов, безусловно, следует считать рукоположение александрийским (феодосианским) патриархом Петром IV 70 (или даже 80) епископов для египетских епархий [9, p. 168; 20, p. 266-267; 21, p. 122-123, 140-141], о чем нам сообщает Иоанн Эфесский (Io. Ephes. Hist. Eccl. 3.1.40 80 епископов; 3.4.12, 3.4.16 - 70 епископов) ${ }^{5}$. Эта цифра неоднократно подвергалась критике, но большинство историков согласны, что даже если она сильно преувеличена, Петр, безусловно, рукоположил епископов для всех (или почти всех) египетских епархий, создав, таким образом, реальную миафизитскую (феодосианскую) ${ }^{6}$ структуру, параллельную халкидонской [20, p. 267; 9, p. 168-169; ср. 12, p. 80]. Однако перед тем, как начать разговор о причинах успешного формирования иерархической вертикали феодосиан, надо посмотреть на более ранний период истории египетских миафизитов. Следует понять, что происходило в Египте со времени депортации патриарха Феодосия в Константинополь (то есть с 536 по 566 гг.) и до рукоположения в патриархи Петра IV (575 г.). 
К сожалению, источники дают достаточно путанную и противоречивую картину этого периода, разобраться в которой не так просто [9, р. 161-168]. Однако если выстроить общую линию, опуская детали, то можно сказать, что этот период характеризовался острой борьбой внутри нехалкидонского лагеря. Феодосианам пришлось конкурировать с юлианитами / гайянитами, к тому же вполне реальной была опасность того, что власть в лагере феодосиан захватят тритеисты, которые с точки зрения Феодосия были явными еретиками. Помимо этого феодосианам предстояло выдержать борьбу внутри себя, поскольку «внешние» конфликты осложнились явлением «контр-патриаршества», когда на Александрийскую кафедру было параллельно избрано два претендента: Феодор и уже упомянутый Петр IV.

Однако этот же период выявил несколько интересных тактических решений. Во-первых, нехалкидониты ищут в ситуации смены верховной власти (в данном случае Юстиниана I на Юстина II) «окно возможностей» для создания полноценной церковной структуры. Мы имеем в виду попытку юлианитов поставить своего патриарха Дорофея, которая закончилась неудачей (новый император, Юстин II, в зародыше присек попытку создания в Египте церковной структуры, параллельной официальной) [9, p. 164-165]. Во-вторых, имела место определенная «поликонверсия», что видно на примере халкидонского патриарха Аполлинария (551-569/570 гг.), возможно, перешедшего в стан халкидонитов из стана феодосиан (что в таком случае ему мешало при благоприятных обстоятельствах перейти обратно?). Наконец, видна попытка разных групп найти некий альянс между собой. Уже упомянутый нами Дорофей в некоторых источниках фигурирует как объединительная фигура гайянитов и феодосиан, а поставление гайянитами епископом некоего Элпидия (ок. 565 г.) можно трактовать как попытку найти альянс с официальной Церковью после того, как Юстиниан в конце жизни начал проявлять симпатии к учению о нетленности тела Христа после воплощения и до воскресения, о которых, вероятнее всего, в Египте было известно. Впрочем, Юстиниан эту попытку жестко присек, блокируя всякую возможность созда- ния параллельной церковной структуры [9, p. 163-164]. С другой стороны, подобные альянсы наталкивались на сопротивление определенных групп (в частности, в стане феодосиан) [9, p. 165-166], что в свою очередь создавало новые расколы и новые потенциальные союзы.

Таким образом, перед нами период максимальной бифуркации, результатом которой часто бывает окончательный выбор пути с последующей его институционализацией. Совершенно ясно, что создание новой феодосианской иерархии - это событие, в основе которого лежит сложная конфигурация объективных и субъективных / случайных факторов. В разряд последних можно отнести победу Петра IV над своим конкурентом Феодором (о предполагаемых причинах его победы [12, p. 8]). Секретарем Петра IV, как известно, был Дамиан, будущий патриарх, роль которого в создании новой конкурентоспособной структуры не менее значима, чем роль Петра в самом факте ее появления. Победа его противника, Феодора, ставила бы под вопрос успешность всего предприятия [12, p. 9].

Но каковы были объективные факторы, способствующие победе нового начинания? Почти все они неплохо разобраны в новейшей историографии [9, p. 180-186; 8, p. 47-56]. Первым можно считать усилившуюся (после смерти Юстиниана) регионализацию Империи и значительное усиление местных провинциальных элит (в частности, земельной аристократии) при Юстине II [8, p. 55]. Совершенно очевидно, что ослабление центральной власти и перехват инициативы на местах создавали благоприятные условия для нарождающейся нехалкидонской иерархии: как показывают документальные источники, феодосианские епископы очень неплохо ладили с местными властями [12, p. 143, 174, 191, 192; 3, с. 154-155].

Вторым фактором можно считать расширение сферы применения коптского языка. При этом надо оставить прошлому теории конца XIX - начала XX в. о выборе языка в качестве маркера «национализма» или этнической идентичности. Выбор языка (коптского или греческого) в Египте поздней Античности - это выбор по принципу функции (напр., личное письмо или документ) и контекста (напр., церковное или светское, официальное или частное), а не по принципу «гре- 


\section{ВИЗАНТИЙСКОЕ ПРАВОСЛАВИЕ}

ки» против коптов, север против юга, город против хоры, богатые против бедных и т. д. [8, p. 49]. До описываемого периода в интеллектуальной сфере однозначно доминировал греческий: это был язык высокой культуры и литературы, церковного и светского делопроизводства. Коптский был, вероятно, ограничен «регистром» повседневной переписки, а сфера обращения коптских литературных текстов (большинство из которых были переводными) носила ограниченный характер: они функционировали либо внутри монашеских общин, либо в пределах маргинальных сообществ разных уровней (гностики, манихеи). В описываемый период, то есть приблизительно с середины VI в., коптский язык начинает широко проникать в церковное и светское делопроизводство, а также в юриспруденцию [8, p. 49]. Эта тенденция хорошо коррелирует с уже обозначенным нами процессом усиления местных элит. Характерно в этом смысле появление в период Дамиана «новой волны» литературы на коптском языке (в основном, гомилетики). Эта литература является оригинальной и предназначается для церковных нужд стремительно институционализирующейся новой нехалкидонской Церкви. Таким образом, процесс литературного расцвета хорошо вписывается в новую экклесиологию: новая Церковь в большей степени, чем ранее, начинает ориентироваться на коптский язык, однако не из-за пресловутого «национализма», a, скорее, с тем, чтобы продемонстрировать свою религиозную инаковость по отношению к халкидонитам. Смежным процессом можно считать повышенный интерес к культам местных святых, прежде всего со стороны местной нехалкидонской церковной элиты, которая старалась привить египетским святым «правильную» миафизитскую родословную [1, с. 156-160; ср. 8, р. 51-53; 12, р. 187].

Существовали и политические предпосылки для успешного выполнения нового проекта. В декабре 574 г. Юстин II стал проявлять первые признаки безумия, и императоpoм de facto становится бывший comes excubitorum (комит дворцовой гвардии) Тиберий. Год спустя имела место интронизация Петра IV как патриарха. Не будет большим преувеличением предположить, что феодоси- ане, как ранее гайаниты, попытались воспользоваться тем «окном возможностей», которое потенциально могла предоставить им смена власти в Константинополе ${ }^{7}$. И они оказываются успешнее своих конкурентов. Тиберий не только не преследует вновь избранного патриарха, но и, озабоченный борьбой с персами, отвечает Константинопольскому (халкидонскому) патриарху на его просьбу о преследовании миафизитов, что настоящие враги империи - это не собратья-христиане внутри, а варвары вдоль ее границ [9, р. 170]. Эту фразу Иоанн Эфесский атрибутирует Тиберию (Io. Eph. Eccl. Hist. 3.1.37), а затем приписывает те же представления императору Маврикию (Io. Eph. Eccl. Hist. 3.3.12). Ф. Бут, об этом упоминающий, не придает, на наш взгляд, данным свидетельствам особого значения. Но при всех сложностях интерпретации этих мест $^{8}$, они по сути могут указывать на существенную эволюцию в умах византийской правящей элиты, которая здесь уже максимально близко подошла к смене экклезиологической модели. Если ранее господствующей идеей было представление «одна Империя - одна Церковь», оправдывающая репрессивные меры по отношению к «еретикам» и нацеленная на унификацию религиозных институтов, пусть и путем сомнительных уний, то новая модель предполагает сосуществование в границах одной Империи разных Церквей. Ф. Бут замечает, что феодосиане смогли de facto поломать прежнюю унификационную модель [9, p. 189], но, опираясь на свидетельства Иоанна Эфесского, можно предполагать, что процессы в какой-то степени шли параллельно, и византийская правящая элита (к сожалению, с большим опозданием) двигалась в этом же направлении.

Теперь рассмотрим ряд субъективных факторов, связанных с личностными особенностями Петра IV и Дамиана, а также характерными чертам их церковной политики. Иоанн Эфесский, как известно, высмеивал качество епископов, рукоположенных Петром, указывая, что тот рукополагал и молодых и старых без должной проверки (Io. Eph. Hist. Eccl. 3.4.16). Однако это свидетельство очевидным образом необъективно: Иоанн являлся сторонником сирийца Феодора и полагал, что посвящение Петра было неканоничным. 
Александрийский нехалкидонский клир, по его мнению, намеренно выбрал престарелого Петра, чтобы иметь возможность самостоятельно принимать решения [9, p. 168-169; 12, p. 8]. К тому же, по мнению Иоанна Эфесского, Петр был втянут в интригу против Павла Антиохийского (Io. Ephes. Hist. Eccl. 3.4.12; 3.4.16). Если взвесить все pro et contra сведений, сообщаемых Иоанном, то ситуация могла выглядеть следующим образом: Петр IV сделал свою часть предприятия, которая заключалась в том, чтобы заполнить все пустующие «ячейки» создаваемой вертикали, но, безусловно, если брать в расчет быстроту проведенной операции, то качество вновь избранных кадров могло быть очень разным. Совершенно понятно, что наличие епископов, вынужденных существовать полулегально, но, в то же время, не пользующихся авторитетом у паствы, грозило подорвать жизнеспособность всей создаваемой системы.

Для того, чтобы вновь организованная структура приобрела устойчивый характер, необходим был следующий шаг: коррекция кадров. И с этим вопросом блестяще справился патриарх Дамиан, преемник Петра IV. Интересным эпизодом начала патриаршества Дамиана можно считать его полемику с антиохийским (миафизитским) патриархом Петром Каллиником. Помимо чисто богословских аспектов темы, здесь можно разглядеть и церковнополитические мотивы [9, p. 171-172]. По сути, Дамиан пытался позиционировать себя в качестве преемника одновременно и Феодосия и Иакова Барадея. Эта стратегия предполагала главенство одного неформального авторитета во вновь создаваемой системе, и за ней вполне можно разглядеть следование византийской универсалистской (или, скорее, квази-универсалистской) церковной модели, когда несколько самостоятельных патриархатов признают неформальное главенство одного центра силы (в данном случае - Константинопольского патриархата). Попытка Дамиана «сконструировать» Церковь миафизитов по такому же образцу потерпела сокрушительное поражение, после чего развитие нехалкидонских структур пошло по пути создания автономных центров (прежде всего, египетского и сирийского).

А вот в границах своего домена деятельность Дамиана была куда успешнее. По об- щему мнению, он сумел сильно поднять моральные стандарты и авторитет феодосианского епископата [12, p. 9]. Прямым доказательством этого можно считать тот факт, что пять епископов «гнезда Дамиана» (Иоанн Гермопольский, Руф Гипсельский, Константин Ликопольский, Иоанн Параллос, Писентий из Коптоса) попали в коптские святцы $[12$, р. 9] ситуация почти исключительная, учитывая такую «плотность» святых епископов на относительно короткий период времени. Но даже те, кто туда не вошел и о ком мы знаем лучше других (например, Авраам Гермонтский) ${ }^{9}$, вполне могли бы там оказаться.

Однако до сих пор остается невыясненным вопрос, каким образом Дамиану удалось сделать египетскую миафизитскую организацию столь эффективной. В качестве одной из версий называется верная с тактической точки зрения идея Дамиана учредить на юге Египта викариат, что шло вразрез с вековыми традициями египетской Церкви, но на тот момент времени она стала верным управленческим решением [9, p. 180-186]. При этом викариат, судя по всему, был очень «гибким»право назначать и переназначать викария Дамиан оставил за собой, пресекая, таким образом, возможность концентрации власти на юге в одних руках. Учитывая, что исторически в египетской Церкви отсутствовали митрополии притом, что количество епархий было большим (более сорока), а также значительное географическое удаление юга Египта (а это примерно половина епархий) от Дельты, где находилась резиденция патриарха, такое решение напрашивалось само собой. Однако надо понимать, что не всякий аскет, обладающий хорошими или даже безупречными моральными качествами, может быть хорошим епископом. Но, к сожалению, современные исследователи «эры Дамиана» ограничиваются, в основном, общими замечаниями относительно кадровой политики этого патриарха.

Тем не менее, именно данная проблема является центральной и требует к себе пристального внимания. В свое время мы попытались кратко ответить на этот вопрос [19, p. 276-277]. По нашему мнению, в вопросах кадровой политики Дамиан, меняя часть епископов, назначенных Петром, исходил из тройного принципа: кандидат, безусловно, не дол- 


\section{ВИЗАНТИЙСКОЕ ПРАВОСЛАВИЕ}

жен был иметь каких-либо претензий в морально-нравственном плане, но при этом должен был обладать определенной финансовой независимостью и несомненным проповедническим талантом. На эти предположения нас натолкнули исследования о Писентии [3; 19], который (помимо того, что до своего епископства был монахом) происходил из достаточно зажиточной семьи, а единственная сохранившаяся его проповедь (в день памяти св. Онуфрия) говорит о нем как о талантливейшем проповеднике. Здесь мы имеем прекрасный образец дидактической проповеди, нацеленной на исправление нравов своей паствы. Писентий очень умело использует день памяти св. Онуфрия как повод поговорить совсем о других проблемах: понимая, что рассказывать мирянам о подвигах аскета - зря терять время, он максимально деперсонализирует святого и, используя его популярность, выстраивает целую «иерархию» уподоблений ему для разных сегментов своей паствы (молодежь, семья, чиновники и т. д.), указывая основные грехи и добродетели, свойственные каждой социальной группе.

В качестве другого примера можно привести «Панегирик Аполлону» ${ }^{10}$ - проповедь Стефана (впоследствии епископа Гераклеополя), посвященная игумену монастыря Исаака. Она нацелена на совершенно иную аудиторию - монахов-нехалкидонитов. Проповедь, на наш взгляд, менее выстроена и, в отличие от прозрачного и риторически выверенного стиля Писентия, более неуклюжа, и по стилю напоминает «вязкий» язык второй софистики. Тем не менее она сочетает в себе элементы панегирика, монашеской дидактики и вероучительного «катехизиса». Стефан прославляет аскетические подвиги Аполлона и обильно цитирует его изречения в качестве наставлений, научающих монахов правильным моделям поведения (Steph. Heracl. Pan. Apol. 13, $14,19)$. Одновременно с этим он артикулирует правильную, с его точки зрения, христологию на фоне «заблуждений» халкидонитов (используя при этом распространенные миафизитские клише о том, что халкидониты раздваивают Христа и четверят Троицу) (Steph. Heracl. Pan. Apol. 9).

Как видно из двух приведенных примеров, гомилетика «периода Дамиана» демон- стрирует достаточно продуманные стратегии, нацеленные на серьезную работу внутри нехалкидонской общины Египта: ее сплочение вокруг наиболее авторитетных святых, исправление ее нравов, маркирование по необходимости (как мы это видим в проповеди Стефана) идеологических различий с оппонентами по координатам «свой» - «чужой». В любом случае, назвать вышеупомянутые нами произведения формальными или абстрактными было бы весьма несправедливо. К сожалению, под этим углом зрения гомилетика «периода Дамиана» остается, насколько нам известно, практически неисследованной.

Другой характерной тенденцией является подъем почитания местных святых. Причем, если посмотреть агиографические и гомилетические источники, этот подъем выглядит вполне «проектно». Мы уже писали применительно к почитанию св. Антония, что интерес к святому вызван желанием сделать его одним из символов нехалкидонской идентичности египтян [1, с. 156-160]. Очень характерен в этом смысле приводимый в миафизитской монашеской агиографии ряд святых, которые посещают главного героя перед его кончиной: здесь вполне можно увидеть попытку выстроить «правильную» траекторию преемственности от свт. Афанасия Великого до св. Севира Антиохийского [1, с. 158-159].

Нам уже приходилось писать, что Писентий проводит активную социальную работу [3, c. 144]: имея в своем распоряжении некий фонд из пожертвований, он адресно распределяет средства (сам или через доверенных лиц) среди нуждающихся. Мы в нашем анализе опирались, в основном, на данные агиографии, которая, как известно, является весьма специфичным источником. Однако недавнее исследование Р. Деккер показало, что подобная практика не является выдумкой агиографов: благодаря сохранившемуся архиву Авраама, епископа Гермонтиса, мы знаем, что он обладал подобным фондом и, также как его коллега, адресно распределял эти средства (не в последнюю очередь это было связано с тем, что условием существования монастыря в Дейр эль-Бахари со стороны властей Джеме была организация там социальной работы) [12, p. $51,87-88,194,284]$. 
Результаты грамотной кадровой политики Дамиана, видимо, превзошли все ожидания: мы уже упоминали о том, что пятеро рукоположенных им епископов оказались в коптских святцах (случай почти уникальный). Современные исследования агиографической традиции о Писентии предполагают, что первая версия его Жития (Энкомия) была составлена вскоре после его кончины (632 г.), то есть приблизительно к середине VII в. [12, p. 98]. Таким образом, вопрос о том, почему Дамиану удалось провести в жизнь столь успешную кадровую политику и какими критериями он руководствовался при отборе кандидатов, остается сферой гипотез и требует более углубленного изучения как оставшихся (увы, весьма немногочисленных) биографических данных о епископах его времени, так и «направленного» анализа сохранившихся гомилетических источников.

Другим слабым местом рассуждений современных исследователей (в первую очередь, Ф. Бута) является то значение, какое они придают епископату. Фактически для них он и есть Церковь, тогда как предполагаемая субъектность других групп внутри Церкви (священники, миряне, монахи и т. д.) ими почти не учитывается. Именно эта зависимость толкает Ф. Бута на заключения о том, что кризис нехалкидонского епископата во время Юстиниана (одни епископы ушли в мир иной, другие были депортированы из Египта, третьи перешли в стан халкидонитов) чуть не погубил миафизитскую Церковь. Он, конечно, отдает дань монахам-нехалкидонитам как реальной силе, но, на наш взгляд, уделяет данному фактору недостаточно внимания.

Большим подспорьем для понимания роли нехалкидонского монашества в генезисе Коптской Церкви может служить недавняя работа Р. Деккер по изучению фиванской церковной сети [12; cp. 4]. Благодаря тому, что Деккер применила к значительному (по меркам поздней Античности) массиву документальных источников (острака, папирусы) современную методику исследования социальных сетей (SNA), основные ее выводы могут рассматриваться как вполне объективные. Приведем те из них, которые напрямую касаются нашей темы. Фактически, результаты ее исследований предполагают, что при формировании своих социальных сетей фиванские епископы (Писентий и Авраам) опирались на монашескую сеть, в определенной степени ее центрируя. Мало того, значительный сегмент личных сетей (ego-networks) обоих епископов занимали монахи $(77,8 \%$ из 18 узлов в личной сети Авраама (не считая монахов-клириков), 72,7 \% из 16 узлов у Писентия) [12, p. 173, 233], а местный подвижник Епифаний, пользовавшийся очень высоким авторитетом ${ }^{11}$, являлся, по сути, центральной фигурой фиванской церковной сети. Крайне интересен и вывод Деккер о том, что ок. 600630 гг. Авраам и Писентий оказались вовлечены в региональную феодосианскую сеть, которая сосредоточилась в восьми монашеских общинах, большинство из которых находились в Западных Фивах в епархии Гермонтиса. При поддержке этой сети Авраам и Писентий смогли организовать свои личные социальные сети (ego-networks) и установить свою власть [12, p. 277]. По сути, речь идет о том, что феодосианские епископы, рукоположенные Дамианом, заново отстроили свои епархии, опираясь, прежде всего, на уже существовавшую в регионах монашескую сеть и центрировав ее на себя.

Еще одну группу данных по этой теме предоставляет нарративная традиция об Аврааме из Фаршута, бывшем настоятеле центрального пахомианского монастыря Пбоу времени Юстиниана. Нарратив об Аврааме, сохранившийся фрагментарно, был подробно исследован Дж. Гёрингом, который, насколько это возможно, восстановил весь ход событий $[13 ; 15]$. Вполне вероятно, что практически сразу после Халкидона монахи Пбоу приняли позицию его противников. Однако по каким-то причинам Юстиниан решил сделать этот монастырь халкидонским (возможно, как опору своей политики на юге Египта) [15, p. 60, 66; 13, p. 249]. Когда переговоры с Авраамом успехом не увенчались, в монастырь был послан вооруженный отряд, сместивший Авраама и поставивший нового, халкидонского игумена. В результате ушедший из монастыря Авраам основывает новые монастыри (мужской и женский) возле своего родного селения Фаршут (судя по данным источников довольно успешные), а ставший халкидонским монастырь Пбоу к концу VI в. приходит в пол- 


\section{ВИЗАНТИЙСКОЕ ПРАВОСЛАВИЕ}

ный упадок [15, p. 62]. Таким образом, единственная известная нам попытка халкидонских властей вмешаться в религиозную жизнь монастырей на юге Египта терпит полное поражение.

Одно из наиболее интересных мест всего нарратива - эпизод, когда после диспута в монастыре с чиновником-халкидонитом Авраам велит вымыть водой комнату, где происходил диспут, чтобы очистить ее от халкидонской «заразы» (эпизод оформлен как донос императору от халкидонской группы монастыря Пбоу [15, p. 110-111]). Дж. Гёринг ищет основания для этого «жеста» в особенностях ментальности египетских монахов [14], но для нашей темы важнее обозначить указанную в тексте степень неприятия Халкидона со стороны некоторых монашеских групп, которая ясно там видна при всех литературных особенностях данного рассказа.

Еще одним существенным моментом является тот факт, что крупные монашеские центры юга Египта, такие как Бауит, монастыри Шенуте и (до определенного момента) центры пахомианской «конгрегации», заняли антихалкидонскую позицию. Учитывая размеры этих монастырей, можно с большой долей уверенности утверждать, что они стали центрами притяжения местных жителей в тех номax, где были расположены, также как, возможно, и для населения соседних с ними областей. Сохранившийся документальный материал из Бауита это вполне подтверждает [2, с. 952-953].

Таким образом, можно предполагать, что помимо феодосианского епископата той силой, которая структурировала генезис новой, нехалкидонской Церкви, являлась значительная часть египетского монашества. Феодосианские епископы были очень тесно связаны с ней и, безусловно, в своей политике в первую очередь на нее опирались. Мы вправе задаться вопросом: а что было бы, если бы проект Петpa IV и Дамиана не случился или потерпел бы провал? Все вышеизложенное подводит нас к выводу о том, что до появления феодосианской иерархии нехалкидонские «диссиденты» Египта уже располагали своей сетевой структурой. Однако она имела несколько иную конфигурацию. Это была «ризома» ${ }^{12}$, наиболее значимыми сегментами / центрами кото- рой были монастырские общины (прежде всего, на юге Египта). Они, безусловно, постепенно аккумулировали вокруг себя местных жителей, поддерживая «мерцающие» связи друг с другом. Обрыв таких связей не приводил к исчезновению сети, поскольку общины могли существовать вполне автономно, имея определенный потенциал для восстановления этих связей в будущем.

Как функционировала эта «ризома» наглядно видно не только по документальным источникам из фивейской области, хорошо исследованным Р. Деккер, но и из нарративных источников VI-VII вв. Ограничимся несколькими примерами. После изгнания из Пбоу Авраам остановился в монастыре Шенуте, где скопировал правила шенутианской киновии и отослал их в монастырь Моисея в Абидосе. После этого он пришел в район своего родного селения Фаршут, где основал два монастыря (мужской и женский) [15, p. 38]. В это же время другой монах, апа Аполлон, также покинул Пбоу и переселился в монастырь Исаака, находившийся в районе Гераклеополя. Впоследствии он стал игуменом этого монастыря, значительно его расширил и ввел там «традицию Пахомия и Шенуте», вероятно, речь идет о переходе на общежительный устав (Steph. Heracl. Pan. Apol. 11, 14, 19). Монах монастыря Исаака, составивший панегирик Аполлону, впоследствии стал епископом Гераклеополя (копт. Хнес) [6, p. 1]. Манассия, родственник Авраама, также ушел из пахомианской «конгрегации» и основал свой монастырь возле деревни Перпе, к югу от Фаршута. Энкомий в его честь произнес епископ Диосполя Парва [10]. Таким образом, мы видим широкий по географическому охвату от Гераклеополя (совр. Ихнасья эль-Мадина) до Диосполя Парва (совр. Хив) - круг контактов монахов-нехалкидонитов, тесно связанных с феодосианским епископатом. При этом выпавшие из этой «ризомы» ячейки (монастырь Пбоу, а, возможно, и другие пахомианские монастыри юга Египта) решительным образом удаляются из их исторической памяти. Дж. Гёринг заметил, что возрастание роли Шенуте как одного из отцов-основателей киновии происходило именно в VI в. [15, p. 64]таким образом, шенутианские монастыри в исторической традиции нехалкидонских мона- 
хов замещали выпавший оттуда в VI в. Пбоу (а, возможно, и другие пахомианские центры). И, наконец, еще одна интересная особенность, касающаяся общего для этой «ризомы» «исторического» нарратива: события конфликта Авраама с Юстинианом отражены не только в панегириках, посвященных непосредственно ему, но и в панегириках, посвященных Аполлону и Манассии [15, p. $111-$ 119, 125-126]. Во всех этих произведениях, составленных, безусловно, в VI - нач. VII вв., ясно видна та тенденция, которую Ф. Бут назвал «кривой линзой» (distorting lens) [8, p. 57], а Дж. Гёринг «тотализирующим нехалкидонским дискурсом» (a totalizing nonChalcedonian discourse) $[15$, p. 51,66 ; cp. p. 37 , 43]. Ее характерной особенностью, помимо прочего, является очевидная демонизация Юстиниана [15, p. 43, 54-55].

Другой пример связан с более поздними событиями - попытками императора Ираклия через своего ставленника Кира навязать египетским нехалкидонитам монофелитскую унию. Мы имеем в виду агиографический нарратив, посвященный апе Самуилу из Каламуна, хорошо исследованный А. Алькоком. Отказавшись признать унию и подвергшись за это истязаниям, Самуил бежал из Скита в Фаюм, где основал монашескую общину. Но там он тоже долго не задержался в связи с тем, что фаюмский епископ Виктор перешел на сторону Кира (аль-Мукаукиса). Самуил опять подвергся репрессиям, и только местные чиновники спасли его от окончательной расправы. После этого он бежал в пустыню на юго-западе Фаюма, где в местечке Каламун основал новый монастырь, который довольно скоро стал серьезным религиозным центром в округе ${ }^{13}$. Монастырь, вынужденный существовать как автономная единица, лишенная государственных дотаций, материально поддерживался частью миафизитского епископата и местными элитами: в источниках в качестве донаторов упоминаются епископ Койса Григорий и родственник Самуила, занимавший должность эпарха Пелипа, города на северо-западе Дельты [7]. На данном примере наглядно можно видеть, как изначально автономная ячейка «ризомы» встраивалась в систему связей епископата и местных элит.
В заключение следует указать, что наиболее близкой исторической аналогией египетской монашеской «ризомы» является, на наш взгляд, старообрядческое беспоповство, сумевшее, несмотря на определенную дезинтеграцию (толки), создать структуры, способные сохранять и транслировать свою традицию, проявляя при этом исключительное упорство в сохранении собственной религиозной идентичности.

Результаты. Исследования западных ученых последних лет показывают, что выдвинутое предположение о генезисе Коптской Церкви в период патриаршества Петра IV и Дамиана вполне убедительно. Оно, на наш взгляд, является более аргументированным, чем те две версии, которых было принято придерживаться до этого (см. Введение). Однако эти же исследования демонстрируют ряд существенных изъянов. Во-первых, почти неизученным остается вопрос о причинах столь успешной кадровой политики Дамиана. Вовторых, со счетов (в том числе и для периода, который можно назвать предысторией) сбрасывается столь важный фактор как монашеские общины Египта, не принявшие Халкидон. Исходя из имеющихся на сегодняшний момент данных, можно предполагать, что именно монахи создают изначальные структурные единицы, на которые позже опирается феодосианская иерархия в процессе окончательного генезиса Коптской Церкви. Пришедшие во время Петра IV и Дамиана епископы переводят эту монашескую сеть из состояния «ризомы» на более центрированный уровень. Если бы проект Петра IV и Дамиана потерпел провал, то вполне можно было бы ожидать, что развитие структуры египетских миафизитов шло бы по модели, близкой к русским беспоповцам, имея (в отличие от последних) шанс при стечении благоприятных обстоятельств когда-нибудь в будущем получить епископат и стать полноценной церковной структурой.

\section{ПРИМЕЧАНИЯ}

\footnotetext{
${ }^{1}$ В основу статьи лег текст нашего доклада, сделанного на «Ломоносовских чтениях» в ИСАА МГУ (секция «Религиоведение», подсекция «Христианский Восток») 28 октября 2020 года.
} 


\section{ВИЗАНТИЙСКОЕ ПРАВОСЛАВИЕ}

${ }^{2}$ В статье мы старались использовать нейтральные термины, то есть халкидониты и нехалкидониты (миафизиты), поскольку как восточные халкидонские, так и нехалкидонские (миафизитские) Церкви используют в своей официальной титулатуре термин «православная», ср. англоязычные официальные названия: Russian Orthodox Church, Coptic Orthodox Church. Поскольку в русскоязычной традиции определение «православные» уже давно закрепилось за восточными халкидонскими Церквям, то во избежании путаницы в статье мы используем словосочетание «Коптская Церковь», избегая прибавления к нему определения «православная».

${ }^{3}$ Петр IV - 34-й патриарх престола св. Марка согласно официальной титулатуре Коптской Церкви. О нем известно, что он был диаконом в доме патриарха Феодосия во время насильственного удерживания последнего в Константинополе (или около него). Затем он стал священником в Александрии, а после - монахом в монастыре Энатон. Петр был кандидатом на патриаршество от александрийского клира, который был недоволен рукоположением «альтернативного» патриарха - Феодора. Дамиан - 35-ый патриарх престола св. Марка. Был эллинизированым сирийцем. В частности известно, что его отец и брат были чиновниками в Эдессе. Подвизался сначала в Скиту. Затем, став диаконом и секретарем патриарха, поселился в монастыре Энатон, который тот выбрал в качестве своей резиденции. В период своего патриаршества проявил себя как прекрасный организатор, а также богослов и полемист. В частности, ему удалось окончательно ликвидировать остатки сект мелетиан и акефалов.

${ }^{4}$ О корректности и эффективности использования метода SNA для анализа эпистолографических источников периода Античности и Средних веков см. [12, p. 16-19], конкретный пошаговый алгоритм работы с применением компьютерных программ описан там же [12, p. 23-26, 30-43]. См. также [4, с. 406].

${ }^{5}$ Как известно, «Церковная история» Иоанна Эфесского была написана в трех частях. Из всех трех частей сохранились лишь незначительные фрагменты второй и значительные - третьей, которая нас и интересует. Сохранившийся текст третьей части был издан Э. Бруксом [16]. При цитировании источника первая цифра означает часть, вторая - книгу, третья - главу. При исследовании мы ориентировались на латинский перевод Брукса [16, vol. 2] и английский перевод, опубликованный в интернете [17].

${ }^{6}$ Термин «феодосианский», применительно к епископату, созданному Петром IV и Дамианом, условен. Иногда применительно к нему используется термин «севирианский» [8; 9]. Суть в том, что этот епископат придерживался богословских взглядов Севира и Феодосия, а не их оппонентов из миафизитского лагеря (Юлиана, Гайяна или тритеистов).

${ }^{7}$ Причем обе феодосианские партии: предположительно, рукоположение Феодора состоялось в один год с рукоположением Петра (575 г.) с разницей в несколько месяцев [9, p. 167, note 82].

${ }^{8} \mathrm{~B}$ обоих эпизодах на вопрос императора, являются ли нехалкидониты еретиками, Константинопольский патриарх отвечает отрицательно, что создает определенные сложности при интерпретации этих мест. Следует также учесть, что в сирийском тексте [16, t. 1, p. 47] стоит греческое заимствование (то есть именно еретики), не оставляющее сомнений, что имелось в виду. Высказывалось мнение, что такое отношение было связано с общей позицией миафизитов (точнее - «диакриноменов»), проводивших различие между учением папы Льва, которое они отвергали, и учением св. Кирилла Александрийского, которого они придерживались, тогда как Халкидонский собор объявил, что оба эти учения находятся в полном согласии друг с другом: см. [17, Book 3].

${ }_{9}$ О морально-нравственных качествах Авраама говорит его сохранившийся архив, исследованный в диссертации М. Краузе [18] и монографии Р. Деккер [12].

${ }^{10}$ На сегодняшний момент есть два издания Панегирика: К. Куна [5] и размещенная на сайте academia.edu публикация А. Алькока [6], где внесены некоторые исправления в коптский текст, изданный Куном, и предложен новый комментированный английский перевод. Ссылки оформляются на параграфы текста, идентичные у Куна и Алькока.

${ }^{11}$ Фактически он являлся holy man - в том значении, какое придает этому термину П. Браун.

12 Термин «ризома» (то есть «корневище») широко используется в философии постмодернизма для обозначения явления с принципиально нелинейным способом организации целостности. Еще одним синонимом слова «ризома» может быть слово «грибница». Данный термин используется нами для обозначения определенного характера (конфигурации) сетевой социальной структуры, которая носит горизонтальный характер и состоит из центров, способных функционировать в автономном режиме, но поддерживающих пульсирующие («мерцающие») связи друг с другом, которые могут усиливаться или ослабляться.

${ }^{13} \mathrm{~K}$ сожалению, археологических раскопок Каламуна не проводилось. В ХІХ в. монахи, восстанавливавшие монастырь, снесли значительную часть древних построек. Однако из описаний средневековых арабских авторов (Абу аль-Макарим, аль-Макризи), европейских путешественников Нового времени (Иоанн Георг, Дж. Б. Бельцони) и бла- 
годаря сохранившимся руинам можно сделать вывод, что монастырь был значительным религиозным центром в VII в. и позднее [11].

\section{СПИСОК ЛИТЕРАТУРЫ}

1. Войтенко, А. А. Культ св. Антония Великого в Византийском Египте / А. А. Войтенко // Византийский временник. - 2013. - Т. 72, № 97. - С. 147-165.

2. Войтенко, А. А. Культ св. Аполлона и Фиба в позднеантичном Египте / А. А. Войтенко // Вестник древней истории. - 2019. - Т. 79, № 4. - С. 938-957.

3. Войтенко, А. А. Пастырь и его паства: проповедь епископа Писентия из Коптоса в день памяти Онуфрия Великого / А. А. Войтенко // Диалог со временем. - 2015. - № 53. - С. 139-158.

4. Войтенко, А. А. Рецензия на кн. : Dekker R. Episcopal Networks and Authority in Late Antique Egypt: Bishops of the Theban Region at Work. Leuven: Peeters, 2018. xvi, 350 p. (Orientalia Lovaniensia Analecta, 264). ISBN 978-9-0429-3560-0 / А. А. Войтенко // Византийский временник. - 2020. - Т. 104. C. $404-410$.

5. A Panegyric on Apollo, Archimandrite of the Monastery of Isaac, by Stephen, Bishop of Heracleopolis Magna. In 2 vols. Vol. 1. Text / ed. by K. H. Kuhn / Louvain : Secrétariat du CorpusSCO, 1978. - 63 p. - (Corpus scriptorum Christianorum orientalium. Scriptores Coptici ; T. 39); Vol. 2. Versio. 41 p. - (Corpus scriptorum Christianorum orientalium. Scriptores Coptici ; T. 40).

6. Alcock, A. Panegyric on Apollo by Stephen Bishop of Hnês / A. Alcock. - 58 p. - Electronic. text data. - Mode of access: https://www.academia. edu/ 37792409/Panegyric_on_Apollo (date of access: 19.12.2020). - Title from screen.

7. Alcock, A. Samu'il ofQalamun, Saint/A. Alcock; ed. by A.S. Atiya // Coptic Encyclopedia. - New York : Macmillan, 2002. - Vol. 7. - P. 2092a-2093b.

8. Booth, Ph. A Circle of Egyptian Bishops at the End of Roman Rule. Texts and Contexts / Ph. Booth // Le Muséon. - 2018. - T. 131, nr. 1-2. - P. 21-72.

9. Booth, Ph. Towards the Coptic Church: The Making of the Severian Episcopate / Ph. Booth // Millenium. -2017. - Vol. 14, no. 1. - P. 151-190.

10. Coquin, R.-G. Manasseh, Saint / R.-G. Coquin; ed. by A.S. Atiya // Coptic Encyclopedia. - New York : Macmillan, 2002. - Vol. 5. - P. 1518b.

11. Coquin, R.-G. Dayr Anba Samu'il of Qalamun / R.-G. Coquin, M. Martin, P. Grossmann ; ed. by A.S. Atiya // Coptic Encyclopedia. - New York : Macmillan, 2002. - Vol. 3. - P. 758a-760b.

12. Dekker, R. Episcopal Networks and Authority in Late Antique Egypt: Bishops of the Theban Region at Work / R. Dekker. - Leuven : Peeters, 2018. - xvi, 350 p.
13. Goehring, J. E. Chalcedonian Power Politics and the Demise of Pachomian Monasticism / J. E. Goehring // Goehring, J. E. Ascetics, Society, and the Desert. Studies in EarlyEgyptian Monasticism/J.E. Goehring.-Harrisburg, PA: TrinityPress International, 1999. - P. 241-261.

14. Goehring, J. E. Keeping the Monastery Clean. A Cleansing Episode from an Excerpt on Abraham of Farshut and Shenoute's Discourse on Purity/ J. E. Goehring // The World of Early Egyptian Christianity Language, Literature, and Social Context. Essays in Honor of David W. Johnson / ed. by J. E. Goehring, J. A. Timbie. Washington, D.C. : Catholic Univ. of America Press, 2007. - P. 158-175.

15. Goehring, J. E. Politics, Monasticism, and Miracles in Sixth Century Upper Egypt. A Critical Edition and Translation of the Coptic Texts on Abraham of Farshut / J. E. Goehring. - Tübingen : Mohr Siebeck, 2012. -160 p.

16. Ioannes Ephesus. Historia ecclesiastica pars tertia. In 2 vols. Vol. 1 / ed. E. W. Brooks. - Louvain : Secretariat du CorpusSCO, 1935. - 344 p. - (Corpus scriptorum Christianorum orientalium. Scriptores Syri ; T. 54); Vol. 2. Versio. - Louvain : Secrétariat du CorpusSCO, 1936. - 263 p. - (Corpus scriptorum Christianorum orientalium. Scriptores Syri ; T. 55).

17. John of Ephesus. Ecclesiastical History, Third Part. - Electronic. text data. - Mode of access: https:// www.tertullian.org/fathers/index.htm\#John_of_Ephesus (date of access: 15.12.2020). - Title from screen.

18. Krause, M. Apa Abraham von Hermonthis. Ein oberägyptischer Bischof um 600. PhD-Dissertation. 2 Bd. Bd. 1. - Berlin, 1956. - V, 137 S.; Bd. 2. - 392 S.

19. Voytenko, A. Le saint comme une "syntaxe". L'homélie de Pesynthios, évêque de Coptos, en l'honneur de Saint Onuphre le Grand / A. Voytenko ; éd. par A. Boud'hors [et al.] // Études coptes XVI. Dixhuitième journée d'études (Bruxelles, 22-24 juin 2017). Paris : Éditions de Boccard, 2020. - P. 263-280.

20. Wipszycka, E. Les élections épiscopales en Égypte aux $\mathrm{VI}^{\mathrm{e}}-\mathrm{VII}^{\mathrm{e}}$ siècles / E. Wipszycka ; ed. by J. Leemans [et al.] // Episcopal Elections in Late Antiquity. - Berlin : de Gruyter, 2011. - P. 259-291.

21. Wipszycka, E. The Alexandrian Church. People and Institutions / E. Wipszycka. - Warsaw : University of Warsaw, 2015. - 485 p.

\section{REFERENCES}

1. Voytenko A.A. Kult sv. Antoniya Velikogo v Vizantiyskom Egipte [The Cult of St. Anthony the Great in Byzantine Egypt]. Vizantiiskii vremennik [Byzantina Chronika], 2013, vol. 72, no. 97, pp. 147-165.

2. Voytenko A.A. Kult sv. Apollona i Fiba v pozdneantichnom Egipte [The Cult of St. Apollo and Phib in Late Antique Egypt]. Vestnik drevney istorii 


\section{ВИЗАНТИЙСКОЕ ПРАВОСЛАВИЕ}

[Journal of Ancient History], 2019, vol. 79, no. 4, pp. 938-957.

3. Voytenko A.A. Pastyr i ego pastva: propoved episkopa Pisentiya iz Koptosa v den pamyati Onufriya Velikogo [Shepherd and His Flock: The Sermon of Bishop Pysentius of Coptos on the Day of the Memory of Onnophrius the Great]. Dialog so vremenem [Dialogue with Time], 2015, no. 53, pp. 139-158.

4. Voytenko A.A. Retsenziya na kn.: Dekker R. Episcopal Networks and Authority in Late Antique Egypt: Bishops of the Theban Region at Work [Book Review. Dekker R. Episcopal Networks and Authority in Late Antique Egypt: Bishops of the Theban Region at Work]. Leuven, Peeters, 2018. xvi, 350 p. (Orientalia Lovaniensia Analecta, 264). Vizantiiskii vremennik [Byzantina Chronika], 2020, vol. 104, pp. 404-410.

5. Kuhn K.N., ed. A Panegyric on Apollo Archimandrite of the Monastery of Isaac by Stephen Bishop of Heracleopolis Magna. In 2 Vols. Louvain, Secrétariat du CorpusSCO, 1978. Vol. 1. Text. 63 p. (Corpus scriptorum Christianorum orientalium. Scriptores Coptici; t. 39); Vol. 2. Versio. 41 p. (Corpus scriptorum Christianorum orientalium. Scriptores Coptici; t. 40).

6. Alcock A. Panegyric on Apollo by Stephen Bishop of Hnês. 58 p. URL: https://www.academia.edu/ 37792409/Panegyric_on_Apollo(accessed 19 December 2020).

7. AlcockA. Samu'il ofQalamun, Saint. Atiya A.S., ed. Coptic Encyclopedia. New York, Macmillan, 2002, vol. 7, pp. 2092a-2093b.

8. Booth Ph. ACircle of Egyptian Bishops at the End of Roman Rule. Texts and Contexts. Le Muséon, 2018, T. 131, nr. 1-2, pp. 21-72.

9. Booth Ph. Towards the Coptic Church: The Making of the Severian Episcopate. Millenium, 2017, vol. 14, no. 1, pp. 151-190.

10. Coquin R.-G. Manasseh, Saint. Coptic Encyclopedia. NewYork, Macmillan, 2002, vol.5, p. 1518b.

11. Coquin R.-G., Martin M., Grossmann P. Dayr Anba Samu'il of Qalamun. Coptic Encyclopedia. New York, Macmillan, 2002, vol. 3, pp. 758a-760b.

12. Dekker R. Episcopal Networks and Authority in Late Antique Egypt: Bishops of the Theban Region at Work. Leuven, Peeters, 2018. xvi, 350 p.
13. Goehring J.E. Chalcedonian Power Politics and the Demise of Pachomian Monasticism. Goehring J.E. Ascetics, Society, and the Desert. Studies in Early Egyptian Monasticism. Harrisburg, PA, Trinity Press International, 1999, pp. 241-261.

14. Goehring J.E. Keeping the Monastery Clean. A Cleansing Episode from an Excerpt on Abraham of Farshut and Shenoute's Discourse on Purity. Goehring J.E., Timbie J.A., eds. The World of Early Egyptian Christianity Language, Literature, and Social Context. Essays in Honor of David W. Johnson. Washington, D.C., Catholic Univ. of America Press, 2007,pp. 158-175.

15. Goehring J.E. Politics, Monasticism, and Miracles in Sixth Century Upper Egypt. A Critical Edition and Translation of the Coptic Texts on Abraham of Farshut. Tübingen, Mohr Siebeck, 2012. $160 \mathrm{p}$.

16. Brooks E.W., ed. Ioannes Ephesus. Historia ecclesiastica pars tertia. In 2 Vols. Louvain, Secretariat du CorpusSCO, 1935. Vol. 1. Text. 344 p. (Corpus scriptorum Christianorum orientalium. Scriptores Syri; t. 54); Vol. 2. Versio. Louvain, Secrétariat du CorpusSCO, 1936. 263 p. (Corpus scriptorum Christianorum orientalium. Scriptores Syri; t. 55).

17. John of Ephesus. Ecclesiastical History, Third Part. URL: https://www.tertullian.org/fathers/ index.htm\#John_of_Ephesus (accessed 15 December 2020).

18. Krause M. Apa Abraham von Hermonthis. Ein oberägyptischer Bischof um 600. PhDDissertation. 2 Bd. Berlin, Humboldt University, 1956. Bd. 1. V, 137 S.; Bd. 2. 392 S.

19. Voytenko A. Le saint comme une "syntaxe". L'homélie de Pesynthios, évêque de Coptos, en l'honneur de Saint Onuphre le Grand. Boud'hors A. et al., eds. Études coptes XVI. Dix-huitième journée d'études (Bruxelles, 22-24 juin 2017). Paris, Éditions de Boccard, 2020, pp. 263-280.

20. Wipszycka E. Les élections épiscopales en Égypte aux VIe-VIIe siècles. Episcopal Elections in Late Antiquity. Berlin, de Gruyter, 2011, pp. 259-291.

21. Wipszycka E. The Alexandrian Church. People and Institutions. Warsaw, University of Warsaw, 2015. 485 p. 
A.A. Войтенко. Патриаршество Петра IV и Дамиана как время генезиса Коптской Церкви

\section{Information About the Author}

Anton A. Voytenko, Doctor of Sciences (History), Leading Researcher, Centre for Egyptological Studies of the Russian Academy of Sciences, Prosp. Leninskiy, 29, Bld. 8, 119071 Moscow, Russian Federation, cesras@cesras.ru,https://orcid.org/0000-0002-3895-9909

\section{Информация об авторе}

Антон Анатольевич Войтенко, доктор исторических наук, ведущий научный сотрудник, Центр египтологических исследований РАН, просп. Ленинский, 29, стр. 8, 119071 г. Москва, Российская Федерация, cesras@cesras.ru, https://orcid.org/0000-0002-3895-9909 